\title{
Spatial Pattern of Intra- Urban Poverty of Ikere- Ekiti, Southwestern Nigeria.
}

\author{
Ayeni, Gabriel Olusegun (Ph.D) ${ }^{1}$, Prof. Adebayo, Williams Oluwole ${ }^{2}$. \\ ${ }^{1}$ Ekiti State Community and Social Development Agency, Plot 20, Bank Road, Besides GT Bank, \\ ${ }^{2}$ Department of Geography and Planning Sciences, Faculty of the Social Sciences, Ekiti State University, Ado-
} Ekiti, Nigeria.

\begin{abstract}
This study used Geographical Information Systems to evaluate the spatial pattern of intra-urban poverty of Ikere-Ekiti. About 100 poverty variables were subjected to Factorial Analysis statistics and the results of the first five factors: Income, Housing characteristics (14.65\%); Commerce and Communication (8.98\%); Educational facilities (5.72\%); Roads and Drainages (4.99\%) and Water facilities (4.08\%) were mapped. It was discovered that there was a spatial variation in the intra-urban poverty of the town. Ugele and Arokun wards were found to be the poorest compared to other wards. Emphasis of any poverty reduction projects should be focused on measures that would increase the provision and accessibility of the poor to necessary social and physical infrastructure that could improve the life of the urban poor.
\end{abstract}

Keywords:- Communalities. Factor Analysis, Infrastructural facilities, Poverty and Vulnerable.

\section{INTRODUCTION}

Poverty is arguably the single largest moral problem in the world today. The following statistics give a rough indication of the size and severity of the problem. Nearly a billion people are undernourished ( FAO, 2010). On average, 22,000 children die from poverty-related causes every day ( You et al., 2010). The number of people who live without access to improved sanitation facilities is 2.6 billion, and over 800 million live without access to improved drinking water ( UNICEF, 2010). Rates of violence against women are persistently and unacceptably high- in most countries, the likelihood of a woman being a victim of physical or sexual violence during lifetime is between $30 \%$ and $60 \%$ (WHO, 2005). The above painted scenario shows that poverty is an ill wind that blow no good to anybody.

According to the National Bureau of Statistics (NBS), (2011), 60.9\% of the Nigeria population or approximately 100 million people live in abject poverty, that is, living on less than $\$ 1$ or N320 a day. On the other hand, the percentage of Nigerians living in abject poverty has increased from 54\% in 2004 to $61 \%$ in 2010 . In Ekiti State, about $74.8 \%$ of the population had access to water while only $46.9 \%$ had access to clean and safe water; almost $79.4 \%$ of the households used firewood as a source of fuel for cooking, while only $20.6 \%$ used kerosene (EKSCDA, 2010). All these and many more data portrayed Ekiti State as highly vulnerable to poverty.

The urban growth is attributed to both natural population and rural - urban migration. Urbanization contributes to sustained economic growth which is critical to poverty reduction. The economies of scale and agglomeration in cities attract investors and entrepreneurs which is good for overall economic growth. Cities also provide opportunities for many, particularly the poor who are attracted by greater job prospects, the availability of services, and for some, an escape from constraining social and cultural traditions in rural villages. Yet, city life can also present conditions of overcrowded living, congestion, unemployment, lack of social and community networks, and crippling social problems such as crime and violence.

It was estimated that one-third of the people living in developing countries who live in cities live in squatter settlements ( World Bank, 2012). Most inhabitants in World's cities experience urban poverty. Urban poverty is a multi-dimensional phenomenon. The urban poor live with many deprivations. Their daily challenges may include: limited access to employment opportunities and income, inadequate and insecure housing and services, violent and unhealthy environments, little or no social protection mechanisms and limited access to adequate health and education opportunities.

Although, there are many literatures on poverty, most of them have not been able to answer the 'where' question. That is, where are the urban poor located. It is only through the apparatus of Geographical Information System (GIS) that the locations of the poor can be shown. Equally, the era of the predominance of socioeconomic indicators serving as the main source for measuring poverty is ending. A newer, integrated vision of poverty, where both spatial and non spatial components are weighed and measured is emerging through the use of GIS. This paper fosters further an explanation of the subject- through measurement of econometric, 
anthropometric and spatial dimensions for the purpose of planning for levels of poverty in Ikere-Ekiti, a rapidly urbanizing town in South-western Nigeria.

\section{STUDY AREA}

Ikere- Ekiti is located on latitude $7^{0} 25^{\prime} \mathrm{N}$ of Equator and Longitude $5^{0} 19^{\prime}$ East of Greenwich Meridian. The town spreads over an area of about $25 \mathrm{~km}^{2}$ with a population figure of 76,715 (INEC, 2000) and rose up astronomically to 174,815 in 2010 (NPC, 2011) obviously due to sprouting of higher institutions, commercial activities, rural-urban migration and natural increase. The town lies within the equatorial climate belt characterized by alternating tropical wet and dry seasons and classified as Koppen's Aw climatic type ( Ojo, 1980; Adebayo, 1993). Humidity is high with mean annual rainfall of about $1500 \mathrm{~mm}$. Natural vegetation is tropical rainforest but now has been modified by a secondary vegetation known as derived savannah mosaic. These are mixtures of patched forest and grasses. Land use includes farmlands interspersed with fallows and settlements.

The study area is characterized with the basement complex rock type of old-suite pre-Cambrian origin and helps determine the water supply. The rocks are mostly impermeable granite-gnesises, migmatites, as well as extensive areas of schists, phylites, and quartz ( Smith and Mortgomery, 1962). The rocks are neither porous nor permeable except where they are deeply weathered or have zones of weaknesses such as cleavages, joint, fissures, lineaments and softer belts ( Ayoade, 1988). The topography of the study area is made up of undulating terrain almost entirely surrounded by rocks. Some of these rocky outcrops which are mainly deep-seated, bare, lenticular inselbergs are often called by local names such as 'Olosunta', 'Orole', 'Ajaribi', 'Opolokogun', 'Ogerekogun','Egungun', and others. The terrain is generally between $350 \mathrm{~m}-400 \mathrm{~m}$ above the sea level. Landforms also include different types of valleys and erosion residuals such as tabular hills. Most of these hills still reflect the signature of underlying rocks, palimpsests, vicissitudes, or relics of older inselbergs ( Olatunji, 2010).

\section{METHODOLOGY}

For the purpose of this study, both primary and secondary sources of data were employed. Transect walks and Direct Interview were used to collect data on the location of each of the eleven wards that make up the town, Ikere-Ekiti. Opinion and community leaders were engaged in transect walk to move round and helped to determine the boundaries of the wards. Global Positioning System (GPS) was used to capture the locational data of the eleven wards that make up the urban centre ( Fig. 1). The data were later mapped using GIS Arcview 8.3 software.

A total of 210 copies of the questionnaire were distributed using systematic random sampling technique. Out of the 11 wards, 6 wards were identified for the administration of the questionnaire ( Fig. 1). After the first electoral ward, (Atiba/Aofin- 01), every other wards were picked respectively. This shows that every ward has equal chance of being picked. An average of 35 copies of the questionnaire were administered in each ward. Having identified the first household, every 10th household was picked. The results of the collated data using SPSS version 10 were subjected to factor analysis statistics. The over 100 poverty variables converged at the 25 th rotation into 14 poverty factors ( Appendices I \& II).

For proper urban poverty mapping, data for the other wards that were not considered in the course of questionnaire administration were captured using Geostatic Analytical tool called Inverse Distance Weighted (IDW). IDW is based on the algorithm of distance with the assumption that things that are close to one another are more alike than those that are farther apart. Those measured values closest to the prediction location will have more influence on the predicted value than those farther away (Watson and Philip, 1985). IDW therefore, assumes that each measured point has a local influence that diminishes with distance. It determines the power function (p) value by minimizing the Root Mean Square Prediction Error (RMSPE). The RMSPE is a summary statistic quantifying the error of the prediction surface.

\section{RESULTS AND DISCUSSION}

The five poverty factors with factor loadings of not less than $4 \%$ were mapped out for all the eleven wards as follows:

4.1 Income, Housing and Housing characteristics.

Ugele and Aroku wards recorded the least relative mean monthly income in the town while fringes of Oke - Osun, Atoba/aafin, Okeruku wards recorded medium mean monthly income and Are/Araromi, Afao/ Kajola, Agbado/ Oyo, Idemo, Odose wards had high mean monthly income (Fig. 2). In this settlement, there was a sort of relationship between housing type and income distribution. For example, in Ugele and Aroku wards, majority of the inhabitants were students of Ekiti State College of Education who did not earn income while the indigenes were mostly farmers. 
But in Oke-Osun, Agbado/ Oyo, Afao/ Kajola wards, majority were government workers who earned monthly incomes. This further explained the type of housing units in the wards. At Ugele and Aroku wards, most housing units lacked the usual urban services like good toilets, bathrooms, kitchens and electricity. In this part of the town, bathrooms and kitchens were detached separately from the main building ( Fig. 2). Most times, a sort of make-shifts were in common place, whereas, there were 'open defecation' and central dumping sites. Indeed, this area of the town depicted real poverty of housing and housing characteristics. In the other wards, we have in most cases, both toilets, bathrooms and kitchens indoor and

less number of households using them compared to Ugele and Aroku wards where firewood remained the major source of energy used in the kitchens ( Fig.2).

4.2: Commerce and Communication Gadgets.

Commercial activities were very low in Ugele and Aroku wards while Atiba/ Aafin, Are/ Araromi and Ogbonjana wards had medium commercial activities. Afao/ Kajola, Idemo, Oke- Osun, Odose, Agbado/ Oyo wards were relatively high in terms of commercial activities( Fig. 3) This situation was explained by the fact that major roads passed through these wards and therefore creating easy accessibility for commercial activities. In Ugele and Aroku wards, people travelled high mean distance to buy goods and services. Here, there were no markets or stores or shops in most cases. The traditional Oba market at Atiba/ Aafin ward remained their major centre of patronage. In most of the other wards, small shops characterized the commercial landscape apart from the traditional market centre. The level of poverty is equally reflected in the ownership of communication gadgets( Fig. 3). In most of the houses in Ugele and Aroku wards, there were no radio sets, no television sets not to talk of refrigerators and other communication gadgets because these facilities were termed to be luxury to them. Less than $50 \%$ of the respondents could boast of handsets if not for the students' population in these wards ( Fig. 3).

4.3: Educational Facilities.

Agbado/ Oyo and Okeruku wards were characterized by high supply of educational facilities as these wards host the State college of education and some secondary and primary schools ( Fig.4). At Oke- Osun and Atiba wards, there were medium level supply of educational facilities while other wards recorded relatively low supply of educational facilities. There was a sort of 'pull- factor' by the presence of the State College of Education as the two wards experienced more modern structure with educated people living in these areas ( Fig.4).

4.4: Water Facilities.

It should be generally noted that there was scarcity of potable water in the town but some wards suffered more compared to others. For example, Ugele ward and parts of Oke-Osun and Are/Araromi wards usually face acute shortage of water while other parts of Are/ Araromi, Oke-Osun and Aroku wards experienced a relatively medium supply of water facilities ( Fig.5). Other wards were better serviced with water facilities through rainfall, dug-out wells and boreholes, streams and pipe-borne water. The pipe-borne water served a very negligible part of the town while dug-out wells and streams were largely relied upon especially by the urban poor. It was only those who were rich that could afford borehole, thus, the poor usually travelled longer distance to access potable water from both boreholes and pipe borne water outside their neighbourhoods ( Fig.5).

4.5: Roads and Drainage Facilities.

The major road passed through the town from Ado- Ekiti to Akure, Ondo State while other neighbouring towns like Ise- Ekiti and Igbara- Odo were equally served with tarred roads. There were few other secondary arteries that were being serviced with tarred roads thus, parts of Atiba/ Aafin, Okeruku, Ugele, OkeOsun and Aroku wards were poorly serviced with road arteries ( Fig.6). Most houses were not accessible through road (untarred) but through major and minor pathways. At the centre of the town where we had Idemo, Ilapetu/ Ijao, parts of Agbado/ Oyo and Odose wards, roads and drainages were relatively high in supplies while the supplies of roads and drainages in Afao/ Kajola, Are/ Araromi, Odose, Agbado/ Oyo were of a medium level ( Fig.6). Accessibility to urban centre was hampered by the seasonality in the usage of available access roads. There was the need to create more accessible roads to the farmsteads to allow the movement of farm produce to the urban centre. In most of the new developed areas of the town, households were sometimes weary of going out with their vehicles during the rainy season as floods, which are rampant because of lack of good drainages and culverts, became a common phenomenon and handicap ( Fig.6).

\section{CONCLUSION}

It is apparent and clearly evident that the findings generated showed that there was a spatial variation in the intra-urban poverty of the town. For example, Ugele and Arokun wards exemplified high level of poverty relative to other wards. The results of the research work will therefore guide any poverty reduction policies and programmes that the government and or any Donor Agency would want to embark on. The local variation in degree of poverty must be considered before applying a global poverty reduction for the urban centre. Emphasis 
of any poverty reduction projects should be focused on measures that will increase provision and accessibility of the poor to necessary social and physical infrastructure that can improve the life of urban poor. Any decision on sustainable urban development should be woven around the experiences, priorities and recommendations of the urban poor.

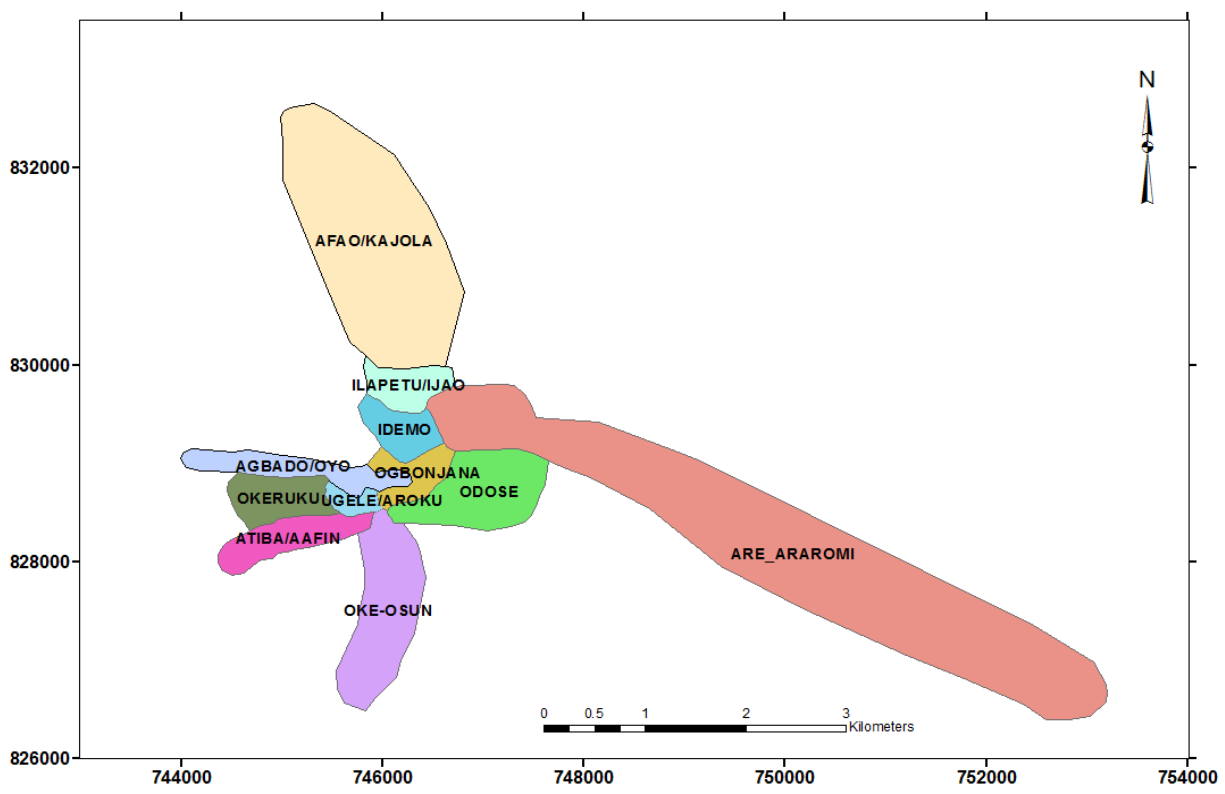

Source: Field Work, 2014

Fig. 1: The Electoral Wards in Ikere- Ekiti

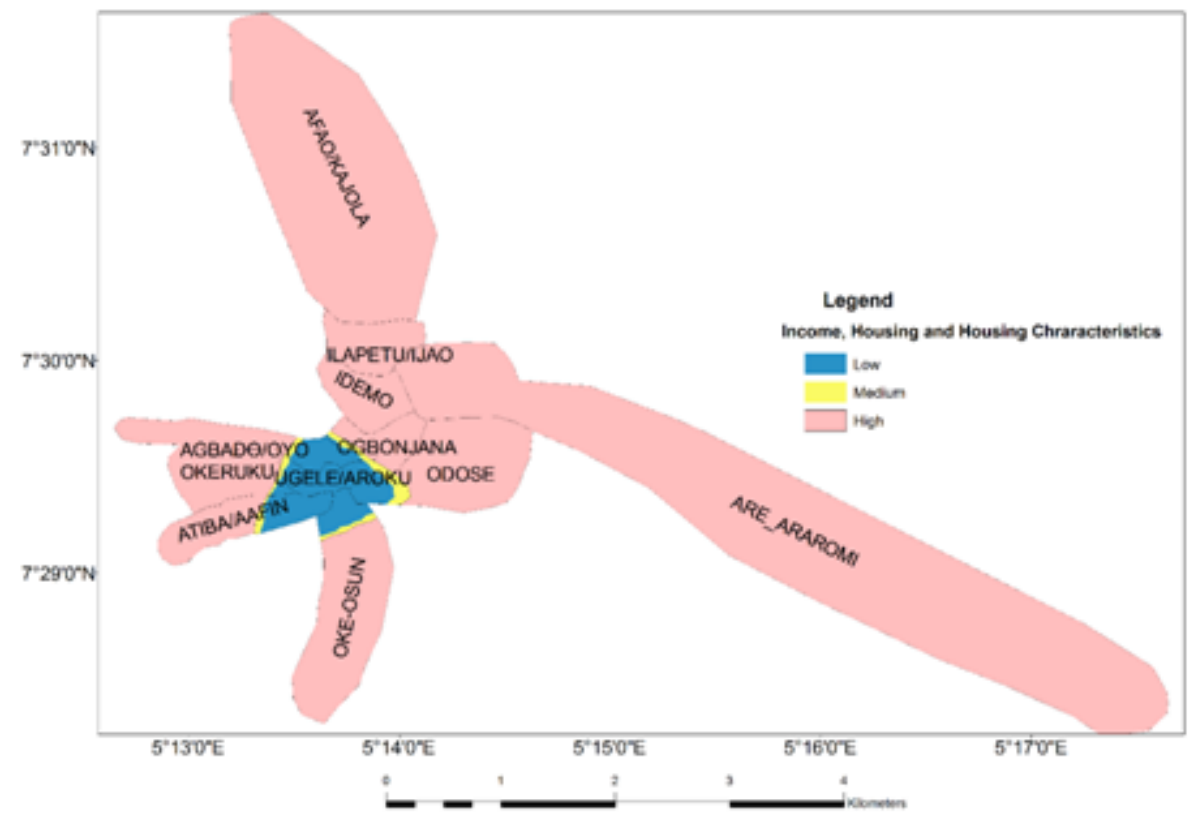

Fig.2: Income, Housing and Housing Characteristics in Ikere- Ekiti

Source: Field Work, 2014. 


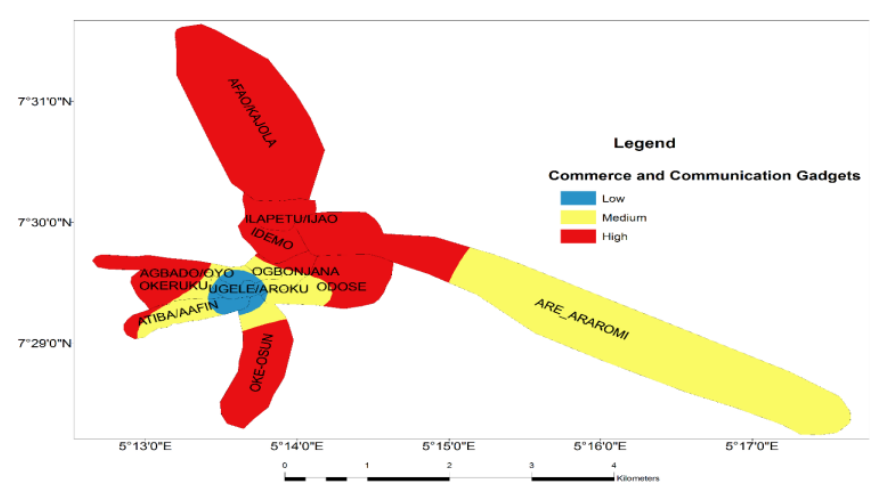

FIG. 3: Commerce and Communication Gadgets in Ikere-Ekiti.

Source: Field work, 2014.

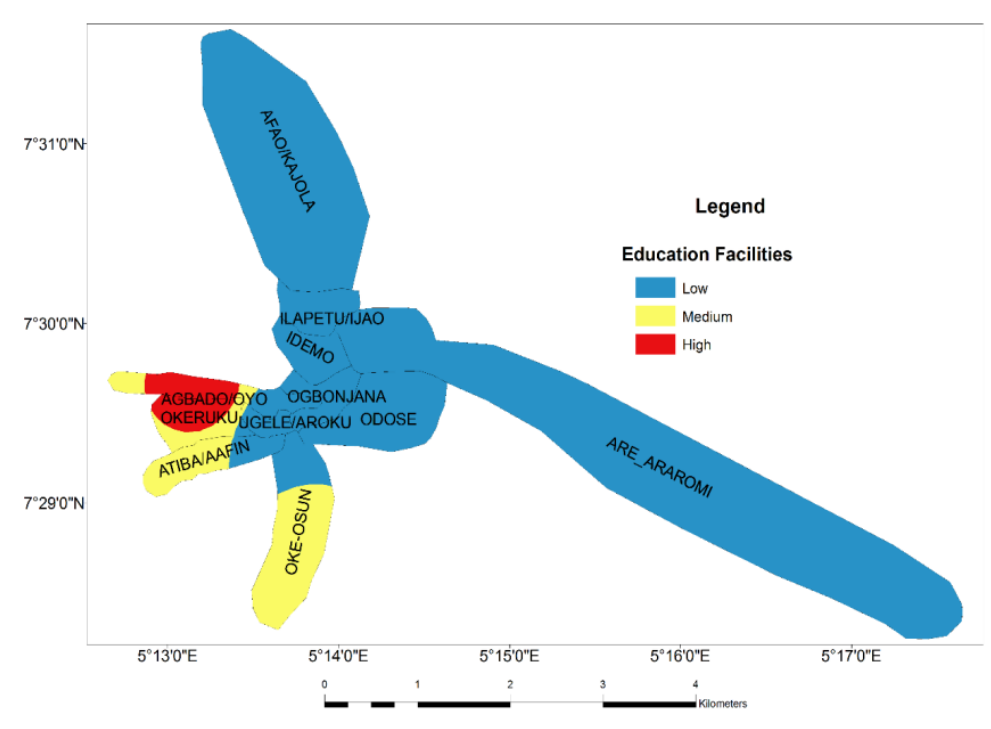

Source: Field Work, 2014

FIG. 4: Education Facilities in Ikere- Ekiti.

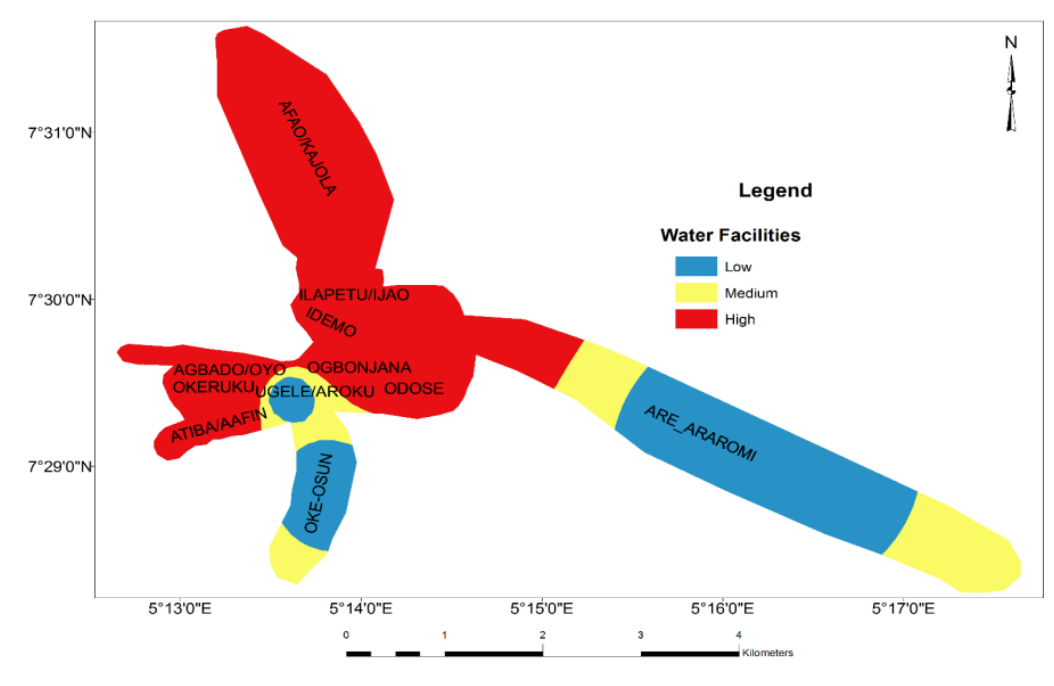

Source: Field work, 2014

FIG. 5: Water Facilities in Ikere - Ekiti. 


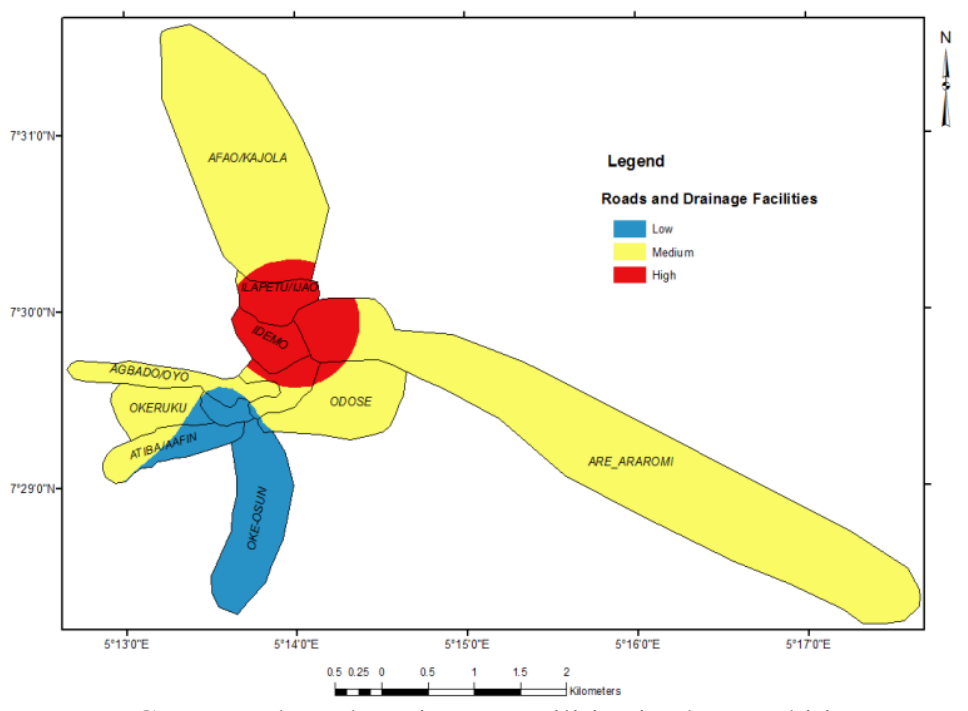

FIG. 6: Roads and Drainage Facilities in Ikere- Ekiti.

Source: Field work, 2014.

\section{REFERENCES}

[1] Food and Agriculture Organization (FAO) (2010). The State of Food Insecurity in the World: Addressing Food Insecurity in Protected http://www.fao.org/docrep/013/11683e/i1683e.pdf.

[2] You, D, and Wadlaw, T. (2010). Levels and Trends in Child Mortality: Report 2010. http://www.childmortality.org/stock/documents/child_Mortality_Report_2010.pdf.

[3] UNICEF (2010). Progress on Sanitation and Drinking Water: 2010 update. http:www.unicef.org/media/files/JMP- $\quad$ 2010Final.pdf.

[4] World Health Organization (WHO) (2005). WHO Multi-Country Study on Women's Health and Domestic Violence against women. http://www.who.int/gender/violence/who_multicountry_study/en/.

[5] National Bureau of Statisrics (NBS) (2011). Poverty Profile of Nigeria (1980-2010).

[6] Ekiti State Community and Social Development Agency (EKCSDA) (2010). Evaluation of the Performance of Community Intervention Fund in Ekiti State. Outcomes of Communities' Micro Projects (2004- 2009).

[7] World Bank (2012). Making Services work for the Poor People. The World Bank. Washington, DC.

[8] Independent National Electoral Commission (INEC) (2000). Guide to Polling/ Registration Centres, Ekiti State, June, 2000.

[9] Ojo, O. (1980). Climates of Africa. Heinemam, Ibadan.

[10] Adebayo, W. O. (1993). Weather and Climate: In Ebisemiju, F.S. (ed.). Ado- Ekiti Region: a Geographical Analysis and Master Plan, Lagos, Apha Prints.

[11] Smith, A. J. \& Montgomery, R. F. ( 1962). Soils and Land uses in Central Western Nigeria. Government Printer, Ibadan National Population Commission ( NPC) (2011). Nigeria Population Census. Analytical Result at the National level, Abuja.

[12] Ayoade, J.O. (1998). Tropical Hydrology and Water Resources. Macmillan Publisher, London.

[13] Olatunji, A. J. (2010). An Evaluation of Entropy Maximization model in estimating the Quality of Household Water Supply and Utilization in Ikere- Ekiti, South-Western Nigeria.. Journal of Geography, Environment and Planning. ISSN: 1595- 4373. Volume 6, No. 1, March.

[14] Watson, D.F. \& Philip, G.M. (1985). A Refinement of Inverse Distance Weighted Interpolation. Geoprocessing, 2: 315-327.

APPENDIX I

\begin{tabular}{|l|l|l|}
\hline COMMUNALITIES. & & \\
\hline & Initial & Extraction \\
\hline V5a - Age & 1 & 0.763629467 \\
\hline V5b - Gender & 1 & 0.685102491 \\
\hline V6 - Marital Status & 1 & 0.766737448 \\
\hline V7 - Level of Education & 1 & 0.756215885 \\
\hline
\end{tabular}




\begin{tabular}{|c|c|c|}
\hline V8 - Religion & 1 & 0.684533737 \\
\hline V9 - Occupation & 1 & 0.776034286 \\
\hline V10 - Household Size & 1 & 0.642613981 \\
\hline V11 - Average Monthly Income (in Naira) & 1 & 0.78422159 \\
\hline V12 - Is the retail market in the area adequate & 1 & 0.690102492 \\
\hline $\begin{array}{l}\text { V13 - Estimated distance of the nearest retail shops to } \\
\text { house }\end{array}$ & 1 & 0.716718831 \\
\hline V14 - Distance to place of work & 1 & 0.719599468 \\
\hline V15 - Mode of Travel & 1 & 0.76321906 \\
\hline V16a - Type of Accomodation Building & 1 & 0.894061434 \\
\hline V16b - No of People Living in the Building & 1 & 0.727058568 \\
\hline V16c - No of Floor & 1 & 0.880704779 \\
\hline V16d - No of Rooms & 1 & 0.793608567 \\
\hline V17 - Nature of Occupancy & 1 & 0.760105058 \\
\hline $\begin{array}{l}\text { V18 - if rented, How much is paid as rent monthly(in } \\
\text { Naira ) }\end{array}$ & 1 & 0.658703529 \\
\hline V19 - Age of Building (in Years) & 1 & 0.718352435 \\
\hline V20 - Materials used for wall construction & 1 & 0.756807321 \\
\hline V21 - If storey building, materials used for decking & 1 & 0.850500769 \\
\hline V22 - Roofing Materials & 1 & 0.669832684 \\
\hline V23 - Wall Finishing & 1 & 0.627539454 \\
\hline V24 - Condition of Wall & 1 & 0.72293327 \\
\hline V25 - Structural Condition of Building & 1 & 0.771054462 \\
\hline V26 - Is the Building Accessible by Road & 1 & 0.67230294 \\
\hline V27 - Source of Drinking Water & 1 & 0.83889667 \\
\hline V28 - Source of Cooking and Washing water & 1 & 0.869402708 \\
\hline V29 - If Pipe-borne water, how regular is the supply? & 1 & 0.836028419 \\
\hline V30 - Do you pay for pipe borne water? & 1 & 0.754239124 \\
\hline V31 - if yes, how much do you pay per month? & 1 & 0.668461229 \\
\hline V32 - Agency Responsible for Water Supply & 1 & 0.700433355 \\
\hline V33 - Distance of Water Source to the HH & 1 & 0.780173284 \\
\hline V34 - Water Resources Location & 1 & 0.766781682 \\
\hline V35 - Location of Bathroom & 1 & 0.862654874 \\
\hline V36 - Number of Households using a bathroom & 1 & 0.924484013 \\
\hline V37 - Location of Toilets & 1 & 0.872307997 \\
\hline V38 - Number of Households using a toilet & 1 & 0.927727731 \\
\hline V39 - Type of Toilet & 1 & 0.749684953 \\
\hline V40 - Location of Kitchen & 1 & 0.90146237 \\
\hline V41 - Number of Households using a Kitchen & 1 & 0.930128632 \\
\hline V42 - Types of Energy used in Kitchen & 1 & 0.59540823 \\
\hline V43 - Distance of Nearest Market & 1 & 0.772502208 \\
\hline V44 - Range of Goods sold in the market & 1 & 0.720121806 \\
\hline V45 - Description of Market Environment & 1 & 0.786658499 \\
\hline $\begin{array}{l}\text { V46 - Are there shopping malls and/or supermarkets } \\
\text { around? }\end{array}$ & 1 & 0.724994478 \\
\hline V47 - Type of Market wanted & 1 & 0.704529422 \\
\hline V49 - What types of goods would you want them to sell & 1 & 0.716589 \\
\hline V50a - Types of Waste generated & 1 & 0.701423801 \\
\hline V50b - Method of waste storage & 1 & 0.635378228 \\
\hline V51 - Methods of Waste Disposal & 1 & 0.680965189 \\
\hline V52 - Frequency of Collection & 1 & 0.739327274 \\
\hline V53 - Condition of Drainage System & 1 & 0.671113034 \\
\hline
\end{tabular}




\begin{tabular}{|c|c|c|}
\hline V54 - Type or Class of Road in Locality & 1 & 0.788554336 \\
\hline V55 - Condition of Road & 1 & 0.717649158 \\
\hline V56 - Is the road provided with drainage? & 1 & 0.822422126 \\
\hline V57 - If yes, kind of drainage available & 1 & 0.727914807 \\
\hline V58 - Do you have difficulty in accessing your house? & 1 & 0.8113596 \\
\hline V59 - If yes, what is responsible for inaccessibilty? & 1 & 0.814248506 \\
\hline V60 - Means of Access to your house & 1 & 0.725437291 \\
\hline V61 - Source of Electricity Supply & 1 & 0.640613689 \\
\hline $\begin{array}{l}\text { V62 - If PHCN, what is the distance of the Nearest } \\
\text { Transformer to the House? }\end{array}$ & 1 & 0.798908758 \\
\hline V63 - Average Monthly Bill Paid by the Household & 1 & 0.799381057 \\
\hline V64a - Category of Health Facilities & 1 & 0.724545391 \\
\hline V64b - Ownership of Health Facility & 1 & 0.745374314 \\
\hline V65 - Condition of Health Facility & 1 & 0.636822639 \\
\hline V66 - Do you have a Police Post in the Neighbourhood? & 1 & 0.822447674 \\
\hline V67 - If available, State type & 1 & 0.790109023 \\
\hline V68 - Distance of Nearest Police Station to House & 1 & 0.845472275 \\
\hline V69 - Distance of Nearest Fire Station to House & 1 & 0.818285227 \\
\hline $\begin{array}{l}\text { V70 - Do you have Postal Agency in your } \\
\text { Neighbourhood? }\end{array}$ & 1 & 0.667820593 \\
\hline V71 - Is there neighbourhood Vigilante in this Area? & 1 & 0.811977898 \\
\hline V72 - How Effective are they? & 1 & 0.827974178 \\
\hline V73 - Who Pays for Security Services? & 1 & 0.844076102 \\
\hline V74 - Type of Communication Gadget owned & 1 & 0.674406246 \\
\hline V75a - Educational Facilities Available & 1 & 0.774549391 \\
\hline V75b - Ownership of Educational Facilities & 1 & 0.654701247 \\
\hline V75c - Distance to HH & 1 & 0.644238708 \\
\hline $\begin{array}{l}\text { V76 - Rating of the Level of Service Delivery provided in } \\
\text { Locality }\end{array}$ & 1 & 0.704814872 \\
\hline V77 - Priority Projects in Community & 1 & 0.703957741 \\
\hline $\begin{array}{l}\text { V78 - Before Facilities were provided, were the people } \\
\text { consulted? }\end{array}$ & 1 & 0.925775675 \\
\hline V79 - If yes, At what Satges were they involved? & 1 & 0.927121413 \\
\hline V80a - Type of Religious Centers & 1 & 0.771675214 \\
\hline V80b - Numbers of Religious Centers & 1 & 0.71309901 \\
\hline V81a - Type of Recreational/Cultural Facilities Available & 1 & 0.881144519 \\
\hline V81b - Number of Recreational/Cultural Facilities & 1 & 0.870790246 \\
\hline V82 - Are you a Member of any Voluntary Organization? & 1 & 0.657494297 \\
\hline V83a - Area of Intervention & 1 & 0.712217342 \\
\hline V83b - & 1 & 0.713502642 \\
\hline $\begin{array}{l}\text { V84 - How Accessible is Land to Womenfolk for } \\
\text { Housing/Property Development }\end{array}$ & 1 & 0.81459562 \\
\hline V85 - Commonest Gender Related Vices/Crimes & 1 & 0.804524896 \\
\hline $\begin{array}{lllll}\text { V86 - Cultural Heritage } & \text { Facilities } & \text { Available in } \\
\text { Neighbourhood } & & & & \\
\end{array}$ & 1 & 0.668249626 \\
\hline V87 - Condition of Drainage System & 1 & 0.724760688 \\
\hline V88 - Environmental Condition in Neighbourhood & 1 & 0.620230878 \\
\hline $\begin{array}{l}\text { V89 - As there been an incident of Outbreak of } \\
\text { Communicable DIseases before? }\end{array}$ & 1 & 0.864967759 \\
\hline V90 - If yes, What are the likely Cause? & 1 & 0.820019501 \\
\hline $\begin{array}{l}\text { V91 - Usual Health Problem caused by Environmental } \\
\text { Conditions }\end{array}$ & 1 & 0.662070957 \\
\hline V92 - What Attracted you to Area? & 1 & 0.640374695 \\
\hline V93 - Would you Relocate from Area if Other Options are & 1 & 0.877091176 \\
\hline
\end{tabular}




\begin{tabular}{|l|l|l|} 
Available? & & \\
\hline V94 - If No, why? & 1 & 0.903025073 \\
\hline V95 - If yes, where else in the town? & 1 & 0.844749575 \\
\hline $\begin{array}{l}\text { V96 - Planning Agency Responsible for Development } \\
\text { Control }\end{array}$ & 1 & 0.652571956 \\
\hline V97 - Sources of Noise in Neighbourhood & 1 & 0.758758619 \\
\hline $\begin{array}{l}\text { V98 - Observed Effects of Noise on Individuals and } \\
\text { Families }\end{array}$ & 1 & 0.77393564 \\
\hline Extraction Method: Principal Component Analysis. & & \\
\hline
\end{tabular}

\begin{tabular}{|c|c|c|c|c|c|c|}
\hline $\begin{array}{l}\text { Total } \\
\text { Variance } \\
\text { Explained }\end{array}$ & & & & & & \\
\hline \multirow[t]{2}{*}{ Component } & $\begin{array}{l}\text { Initial } \\
\text { Eigenvalues }\end{array}$ & & & $\begin{array}{l}\text { Extraction } \\
\text { Sums of } \\
\text { Squared } \\
\text { Loadings }\end{array}$ & & \\
\hline & Total & $\begin{array}{l}\% \text { of } \\
\text { Variance }\end{array}$ & $\begin{array}{l}\text { Cumulative } \\
\%\end{array}$ & Total & $\begin{array}{l}\% \text { of } \\
\text { Variance }\end{array}$ & $\begin{array}{l}\text { Cumulative } \\
\%\end{array}$ \\
\hline 1 & 15.23548041 & 14.6495004 & 14.6495004 & 15.23548041 & 14.6495004 & 14.6495004 \\
\hline 2 & 9.337435396 & 8.978303265 & 23.62780366 & 9.337435396 & 8.978303265 & 23.62780366 \\
\hline 3 & 5.953564515 & 5.724581265 & 29.35238493 & 5.953564515 & 5.724581265 & 29.35238493 \\
\hline 4 & 5.18236709 & 4.983045279 & 34.33543021 & 5.18236709 & 4.983045279 & 34.33543021 \\
\hline 5 & 4.247202074 & 4.083848148 & 38.41927836 & 4.247202074 & 4.083848148 & 38.41927836 \\
\hline 6 & 3.484381415 & 3.350366745 & 41.7696451 & 3.484381415 & 3.350366745 & 41.7696451 \\
\hline 7 & 3.310389974 & 3.183067283 & 44.95271238 & 3.310389974 & 3.183067283 & 44.95271238 \\
\hline 8 & 2.910712274 & 2.798761802 & 47.75147418 & 2.910712274 & 2.798761802 & 47.75147418 \\
\hline 9 & 2.549870181 & 2.451798251 & 50.20327244 & 2.549870181 & 2.451798251 & 50.20327244 \\
\hline 10 & 2.478736902 & 2.383400867 & 52.5866733 & 2.478736902 & 2.383400867 & 52.5866733 \\
\hline 11 & 2.412097282 & 2.319324309 & 54.90599761 & 2.412097282 & 2.319324309 & 54.90599761 \\
\hline 12 & 2.297837449 & 2.209459086 & 57.1154567 & 2.297837449 & 2.209459086 & 57.1154567 \\
\hline 13 & 2.067802476 & 1.988271612 & 59.10372831 & 2.067802476 & 1.988271612 & 59.10372831 \\
\hline 14 & 1.939926322 & 1.865313771 & 60.96904208 & 1.939926322 & 1.865313771 & 60.96904208 \\
\hline 15 & 1.855093505 & 1.783743755 & 62.75278584 & 1.855093505 & 1.783743755 & 62.75278584 \\
\hline 16 & 1.72714951 & 1.660720683 & 64.41350652 & 1.72714951 & 1.660720683 & 64.41350652 \\
\hline 17 & 1.619953195 & 1.557647303 & 65.97115382 & 1.619953195 & 1.557647303 & 65.97115382 \\
\hline 18 & 1.584256549 & 1.523323605 & 67.49447743 & 1.584256549 & 1.523323605 & 67.49447743 \\
\hline 19 & 1.532218034 & 1.473286572 & 68.967764 & 1.532218034 & 1.473286572 & 68.967764 \\
\hline 20 & 1.391207637 & 1.337699651 & 70.30546365 & 1.391207637 & 1.337699651 & 70.30546365 \\
\hline 21 & 1.270559606 & 1.221691929 & 71.52715558 & 1.270559606 & 1.221691929 & 71.52715558 \\
\hline 22 & 1.204015646 & 1.157707352 & 72.68486293 & 1.204015646 & 1.157707352 & 72.68486293 \\
\hline 23 & 1.170767997 & 1.125738459 & 73.81060139 & 1.170767997 & 1.125738459 & 73.81060139 \\
\hline 24 & 1.151717116 & 1.107420304 & 74.91802169 & 1.151717116 & 1.107420304 & 74.91802169 \\
\hline 25 & 1.110239518 & 1.067537998 & 75.98555969 & 1.110239518 & 1.067537998 & 75.98555969 \\
\hline 26 & 0.992169147 & 0.954008795 & 76.93956849 & & & \\
\hline 27 & 0.978713459 & 0.941070633 & 77.88063912 & & & \\
\hline 28 & 0.957454542 & 0.920629367 & 78.80126849 & & & \\
\hline 29 & 0.939289366 & 0.903162852 & 79.70443134 & & & \\
\hline 30 & 0.904522724 & 0.869733389 & 80.57416473 & & & \\
\hline 31 & 0.878363261 & 0.844580059 & 81.41874479 & & & \\
\hline 32 & 0.839057556 & 0.806786111 & 82.2255309 & & & \\
\hline 33 & 0.817375257 & 0.785937747 & 83.01146864 & & & \\
\hline 34 & 0.789725628 & 0.759351565 & 83.77082021 & & & \\
\hline 35 & 0.761819063 & 0.73251833 & 84.50333854 & & & \\
\hline
\end{tabular}


Spatial Pattern Of Intra- Urban Poverty Of Ikere- Ekiti

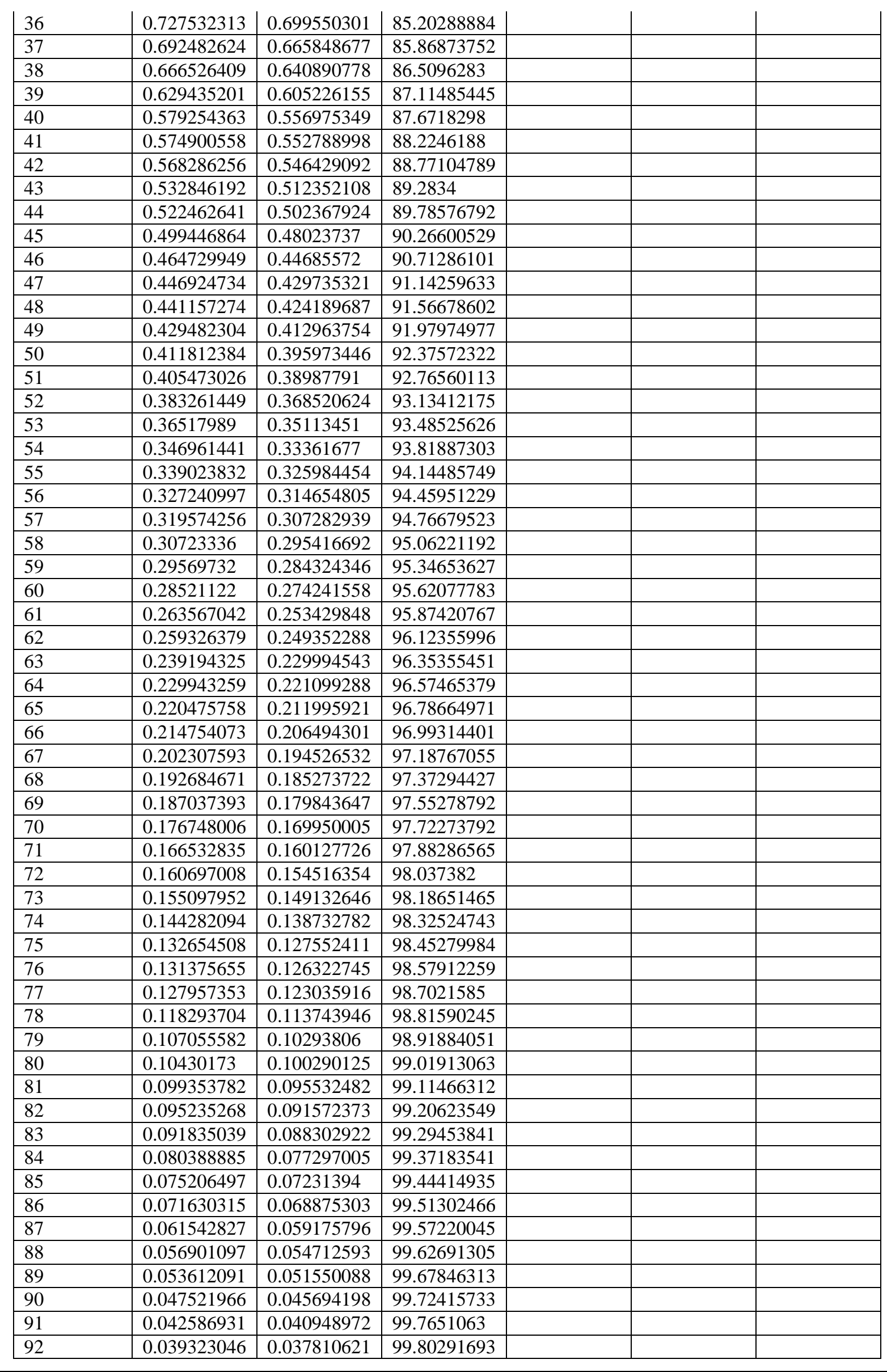


Spatial Pattern Of Intra-Urban Poverty Of Ikere- Ekiti

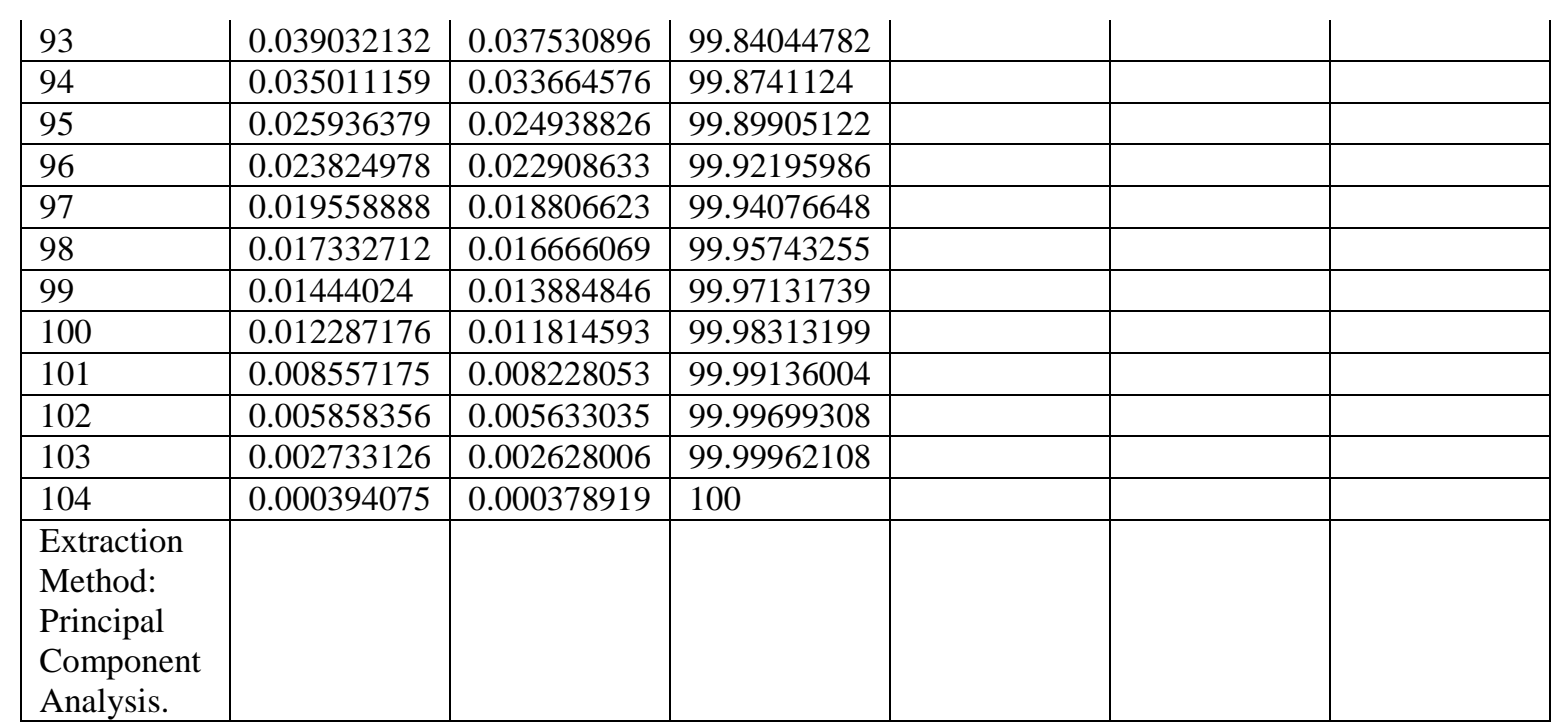

